\title{
Faktor Penentu Audit Report Lag Pemerintah Daerah di Indonesia
}

\author{
Aditya Kurniawan Wicaksono' ${ }^{1}$, Sutaryo ${ }^{2}$ \\ 1,2,Universitas Sebelas Maret, ${ }^{1}$ Badan Pengawasan Keuangan dan \\ Pembangunan \\ 1star.piet@gmail.com, 2sutaryo@staff.uns.ac.id
}

\begin{abstract}
This study aims to determine the effect of internal audit and the assistance of state development audit agency (BPKP) to audit report lag (ATR) at 330 local governments in Indonesia in 2013. Internal audits are proxied with the sufficiency of the number of internal auditors and the number of internal auditors that the local government has indicated, while the assistance of BPKP is projected by the implementation of information system. This research is able to give result that sufficient number of internal auditor, number of trained internal auditor, implementation of information system implementation have negative effect to audit report lag It is also important to implement a reliable system of financial management in order to make the financial management process more accountable and transparent.
\end{abstract}

Keywords: audit internal, audit report lag, asisstance, local government

\begin{abstract}
Abstrak
Penelitian ini bertujuan untuk mengetahui pengaruh audit internal dan asistensi Badan Pengawasan Keuangan dan Pembangunan (BPKP) terhadap audit report lag (ATR) pada 330 pemerintah daerah di Indonesia tahun 2013. ATR diukur dengan jumlah hari dari tanggal penerimaan LKPD sampai dengan tanggal penyerahan laporan audit atas LKPD oleh Badan Pemeriksa Keaungan Republik Indonesia. Audit internal diproksikan dengan kecukupan jumlah auditor internal dan jumlah auditor internal yang didiklatkan oleh pemerintah daerah, sedangkan asistensi BPKP diproksikan dengan implementasi sistem informasi. Penelitian ini mampu memberikan hasil bahwa kecukupan jumlah auditor internal, jumlah auditor internal yang mendapatkan pendidikan dan pelatihan, implementasi sistem informasi berpengaruh negatif terhadap audit report lag. Selain itu penting juga untuk mengimplementasikan sistem yang handal dalam pengelolaan keuangan agar proses pengelolaan keuangan menjadi lebih akuntabel dan transparan.
\end{abstract}

Kata Kunci: audit internal, audit report lag, asistensi, pemerintah daerah

Diterima: 29 Maret 2017; Direvisi: 11 April 2017; Disetujui: 28 April 2017 


\section{PENDAHULUAN}

Dalam Standar Akuntansi Pemerintah (SAP), informasi yang disajikan dalam laporan keuangan bertujuan untuk memenuhi kebutuhan informasi semua kelompok pengguna, antara lain: (a) masyarakat; (b) wakil rakyat, lembaga pengawas, lembaga pemeriksa; (c) pihak yang memberi atau berperan dalam proses donasi, investasi dan pinjaman; dan (d) pemerintah. Agar dapat memenuhi kebutuhan kelompok pengguna, informasi akuntansi dalam laporan keuangan harus memenuhi karakteristik kualitatif atau ukuran-ukuran normatif tertentu, antara lain: (a) relevan; (b) handal; (c) dapat diperbandingkan; dan (d) dapat dipahami. Informasi yang relevan adalah informasi yang dapat mempengaruhi keputusan pengguna.

Informasi yang relevan memiliki: (a) manfaat umpan balik (feedback value), yaitu memungkinkan pengguna untuk menegaskan atau mengkoreksi ekspektasi di masa lalu. (b) manfaat prediktif (predictive value), yaitu dapat membantu pengguna untuk memprediksi masa yang akan datang berdasarkan hasil masa lalu dan kejadian masa kini. (c) disajikan selengkap mungkin, mencakup semua informasi akuntansi yang dapat mempengaruhi pengambilan keputusan dan memperhatikan kendala yang ada. (d) ketepat waktuan (timeliness), yaitu disajikan tepat waktu sehingga dapat berguna dan berpengaruh dalam pengambilan keputusan. Berdasarkan paket Undang-Undang Keuangan Negara, ketepatan waktu publikasi Laporan Keuangan Pemerintah Daerah (LKPD) ditentukan oleh waktu penyusunan laporan keuangan oleh Pemerintah Daerah dan jangka waktu pelaksanaan audit oleh BPK. Jumlah hari kalender antara tanggal akhir tahun finansial dan tanggal laporan audit auditor eksternal yang dikenal sebagai audit delay atau audit reporting lag (ARL). Dengan demikian, ARL dari LKPD akan menentukan ketepat waktuan penerbitan laporan keuangan oleh Pemerintah Daerah.

Berdasarkan Hasil Evaluasi atas Laporan Hasil Pemeriksaan dalam Ikhtisar Hasil Pemeriksaan Semester (IHPS) BPK tahun 2013, 116 Laporan Hasil Pemeriksaan (LHP) diterbitkan melewati batas waktu 6 (enam) bulan sejak tahun anggaran berakhir, 197 LKPD diserahkan kepada BPK melewati 3 (tiga) bulan sejak tahun anggaran berakhir, dan 86 LHP diterbitkan lebih dengan jangka waktu lebih 
dari 2 bulan. Kenyataan tersebut dapat mengakibatkan menurunnya relevansi dari laporan keuangan, sehingga berpotensi menurunkan nilai informasi yang dapat mempengaruhi keputusan pengguna. Selain itu, jika laporan keuangan auditan terlambat diterima oleh pemerintah daerah, maka proses pertanggungjawaban pengelolaan keuangan tahun sebelumnya dan proses penyusunan anggaran tahun berikutnya akan terganggu juga yang pada akhirnya akan mengganggu penyediaan layanan bagi masyarakat. Oleh karena itu, pemenuhan tenggat waktu audit LKPD menjadi hal penting untuk dikaji.

Penelitian terkait ARL pada sektor publik telah banyak dilakukan. Cohen dan Leventis (2012) mengungkapkan bahwa ARL pada pemerintah kota dipengaruhi oleh oposisi yang kuat, re-election, keberadaan tim akuntansi internal, remarks, ukuran pemerintah daerah, dan populasi. Menurut Pizzini, dkk. (2015), ARL dipengaruhi insentif manajemen, sistem pelaporan berkualitas tinggi, keterikatan utang, peraturan negara mengenai proses audit, ukuran pemerintah daerah, kompleksitas audit, dan reputasi auditor.

Salah satu perkembangan terbaru dari literatur terkait ARL adalah peran dari corporate governance terhadap ARL. Naimi, dkk. (2010) dan Abernathy, dkk. (2015) menunjukkan bahwa ARL dipengaruhi oleh frekuensi pertemuan komite audit dan kompetensi keuangan komite audit. Penelitian Abbott, dkk. (2012) menunjukkan bahwa asistensi langsung dari fungsi audit internal kepada eksternal auditor menimbulkan efisiensi yang lebih baik dan mengurangi ARL. Pizzini, dkk (2015) mengindikasikan bahwa audit delay berkurang dengan peningkatan kualitas fungsi internal audit, dan pengurangan tersebut dihasilkan oleh peningkatan kompetensi internal auditor dan kualitas pekerjaan lapangan. Wan-Hussin dan Bamahros (2013) menemukan hubungan yang negatif antara kos yang dikeluarkan untuk fungsi audit internal terhadap audit delay.

Menurut Adams (2013), salah satu isu yang relevan terkait dengan profesi internal audit adalah outsourcing dari jasa internal audit oleh akuntan di luar entitas. Desai, dkk. (2011) berpendapat bahwa auditor internal (in-house) memiliki keterbatasan terkait pengetahuan yang khusus mengenai auditing dan peluang yang lebih tinggi untuk takluk kepada tekanan manajemen. Outsourcing atas IAF juga 
dianggap dapat memberikan objektivitas yang lebih baik, karena auditor outsourcing memiliki kepentingan yang lebih sedikit dan menerima insentif yang lebih sedikit untuk memuaskan keinginan manajemen. Ahlawat dan Lowe (2004) menemukan bahwa IAF secara out-source lebih objektif daripada IAF yang dikelola sendiri oleh perusahaan. Glovers, dkk. (2008) menemukan bahwa ketika risiko inheren tinggi, auditor eksternal akan lebih memilih untuk percaya kepada hasil kerja auditor internal out-source daripada yang menggunakan auditor internal inhouse.

Pada sektor publik di Indonesia, pemerintah daerah tidak memiliki sourcing-arrangement fungsi audit internal yang spesifik/berbeda satu dengan yang lainnya. Seluruh pemerintah daerah memiliki Inspektorat Daerah yang merupakan fungsi audit internal yang berada di lingkungan internal pemerintah daerah. Namun, pemerintah daerah diberikan kewenangan untuk meminta bantuan kepada lembaga di luar lingkup pemerintah daerah untuk membantu dalam melaksanakan fungsi audit internal dan penyusunan laporan keuangannya. Badan Pengawasan Keuangan dan Pembangunan (BPKP) merupakan lembaga pemerintahan nonkementerian yang salah satu tupoksinya adalah melakukan asistensi terkait fungsi audit internal pemerintah daerah, dan dapat diminta oleh pemerintah daerah untuk membantu pelaksanaan fungsi audit internalnya.

Kontribusi penelitian ini ialah untuk menganalisis pengaruh audit internal dan asistensi BPKP terhadap audit reporting lag pada pemerintah daerah di Indonesia. Hal ini disebabkan penelitian mengenai audit report lag yang dikaitkan dengan peran audit internal masih terbatas di Indonesia.

\section{METODE}

Populasi penelitian ini adalah seluruh pemerintah provinsi/kabupaten/kota di Indonesia. Teknik pengambilan sampel yang digunakan adalah purposive sampling, yaitu pengambilan sampel dengan menggunakan kriteria yang ditentukan peneliti berdasarkan kebutuhannya, yaitu pemerintah Provinsi/Kabupaten/Kota di seluruh Indonesia; pemerintah Provinsi/Kabupaten/Kota yang jumlah auditornya dapat diperoleh; Pemda yang jumlah SKPD-nya dapat diidentifikasi; Pemda yang mencantumkan seluruh data yang dibutuhkan untuk pengukuran variabel. 
Penilitian ini menggunakan total sampel sebanyak 330 Pemda dari total 542 Pemda di Indonesia pada tahun 2013 (Komite Pemantauan Pelaksanaan Otonomi Daerah). Sumber Data penelitian ini adalah berdasarkan Laporan Hasil Pemeriksaan (LHP) tahun 2013 dari BPK RI, Ikhtisar Hasil Pemeriksaan Semester I dan II tahun 2013 dari BPK RI, Laporan Pelaksanaan Kegiatan Penyediaan Layanan Informasi Jabatan Fungsional Auditor per 31 Desember 2013 dari BPKP, Laporan Kinerja BPKP tahun 2014 dari BPKP, dan Daftar Pengguna SIMDA per 31 Desember 2013 dari BPKP. Jumlah sampel berdasarkan hasil pemilihan sampel sebagaimana disajikan dalam Tabel 1.

\section{Tabel 1. Pemilihan Sampel}

\begin{tabular}{clc}
\hline No. & \multicolumn{1}{c}{ Keterangan } & Jumlah \\
\hline 1 & Pemerintah Provinsi/Kabupaten/Kota di seluruh Indonesia & 542 \\
2 & Pemerintah Provinsi/Kabupaten/Kota yang jumlah auditornya & (29) \\
& tidak dapat diperoleh & \\
3 & Pemda yang jumah SKPD-nya tidak dapat diidentifikasi & (92) \\
3 & Pemda yang tidak mencantumkan seluruh data yang & (91) \\
& dibutuhkan untuk pengukuran variabel &
\end{tabular}

Dari total 542 Pemda di Indonesia, 29 Pemda tidak dapat diidentifikasi jumlah auditornya. Dari 513 Pemda yang dapat diidentifikasi jumlah auditornya, 115 diantaranya tidak dapat diidentifikasi jumlah SKPD-nya di dalam LKPD Pemda tersebut. Sebanyak 68 Pemda tidak mencantumkan seluruh data yang dibutuhkan. Jadi, total observasi yang terpilih sebagai sampel dalam penelitian ini adalah sebanyak 330 Pemda.

Untuk menguji hipotesis, penelitian ini menggunakan metode analisis regresi berganda. Persamaan regresi yang digunakan adalah sebagai berikut:

$$
\begin{aligned}
\mathrm{ARL}= & \alpha+\beta_{1} \text { IA_PERC }+\beta_{2} \text { DIKLAT }+\beta_{3} \text { SIMDA_KEU }+\beta_{4} \text { SIMDA_BMD }+ \\
& \beta_{5} \text { SIMDA_GAJI }+\beta_{6} \text { SIMDA_PEND }+\beta_{7} \text { BAST }+\beta_{8} \text { EXP }+\beta_{9} \text { TYPE }+\beta_{10} \text { SKPD } \\
& +\mathrm{e}
\end{aligned}
$$


Dimana:

$\begin{array}{ll}\text { ARL } & =\text { Audit Report Lag } \\ \text { IA_PERC } & =\text { Persentase kecukupan auditor } \\ \text { TRAINING } & =\text { jumlah peserta diklat } \\ \text { SIMDA_KEU } & =\text { implementasi SIMDA Keuangan } \\ \text { SIMDA_BMD } & =\text { Implementasi SIMDA BMD } \\ \text { SIMDA_GAJI } & =\text { Implementasi SIMDA Gaji } \\ \text { SIMDA_PEND } & =\text { Implementasi SIMDA Pendapatan } \\ \text { BAST } & =\text { Penyerahan LKPD dari Pemda kepada BPK } \\ \text { EXP } & =\text { Total Belanja Daerah } \\ \text { TYPE } & =\text { Tipe Pemda } \\ \text { SKPD } & =\text { Jumlah SKPD }\end{array}$

Dalam penelitian ini, variabel kontrol yang digunakan adalah tanggal penyerahan LKPD dari Pemda kepada BPK (BAST), dan ukuran daerah (SIZE), yang terdiri atas total belanja daerah (EXP), Tipe Pemda (TYPE), dan Jumlah SKPD (SKPD). Dengan terbatasnya sumber daya auditor eksternal pada BPK, LKPD yang terlambat masuk akan menjadi tidak tertangani sehingga berpotensi menimbulkan ARL yang lebih tinggi. Karena itu, penulis memasukkan tanggal BAST LKPD dari Pemda kepada BPK (BAST) sebagai variabel kontrol.

Ukuran entitas merupakan variabel yang banyak digunakan untuk memprediksi ARL. McLelland dan Giroux (2000) menggunakan populasi, Pizzini, dkk. (2015) menggunakan jumlah belanja daerah, Cohen dan Leventis (2012) menggunakan jumlah asset daerah atau, dan Wan-Hussin dan Bamahros (2013) menggunakan logaritma natural dari total aset. Pada penelitian ini, penulis menggunakan belanja daerah (EXP) sejalan dengan penelitian Pizzini, dkk. (2015), dan menggunakan dua variabel kontrol tambahan, yaitu Tipe Pemda (TYPE), dan Jumlah SKPD (SKPD).

Tipe Pemda (TYPE) diukur dengan skala nominal, yaitu 1 untuk Pemerintah Provinsi, 2 untuk Pemerintah Kota, dan 3 untuk Pemerintah Kabupaten. Pemerintah yang lebih besar akan cenderung mengalami peningkatan jumlah transaksi keuangan, sehingga akan lebih memakan waktu untuk melakukan audit dan 
menghasilkan ARL yang lebih banyak. Namun, pemerintah provinsi dan kota umumnya memiliki akses yang lebih mudah dibandingkan dengan pemerintah kabupaten. Penulis menggunakan Jumlah SKPD (SKPD) sebagai variabel kontrol, karena juga merupakan salah satu yang dianggap mewakili ukuran daerah (SIZE). Pemda yang memiliki lebih banyak SKPD akan membutuhkan pertanggungjawaban keuangan yang lebih kompleks, dan sesuai dengan penghitungan kebutuhan formasi JFA, akan membutuhkan jumlah auditor internal yang lebih banyak.

\section{HASIL DAN PEMBAHASAN}

Penelitian ini menggunakan ARL sebagai variabel dependen. Jumlah sampel (n) dalam penelitian ini adalah 330 sampel Rata-rata ARL menunjukkan -2.3242 yang berarti rata-rata waktu pelaksanaan audit adalah 2.3242 hari lebih cepat daripada waktu maksimal pelaksanaan audit yaitu 61 hari, sehingga rata-rata waktu audit adalah 58.6758 hari. ARL terendah, yaitu -12 hari, terjadi pada Pemerintah Daerah Kab. Dompu. ARL tertinggi, yaitu 17 hari, terjadi pada Pemerintah Provinsi Papua Barat. Hasil dari pengujian statistik deskriptif dapat dilihat pada Tabel 2.

Variabel independen dalam penelitian ini adalah IA_PERC, DIKLAT, SIMDA_KEU, SIMDA_BMD, SIMDA_GAJI, dan SIMDA_PEND. Rata-rata IA_PERC menunjukkan 0.1982 atau 19.82\%, yang berarti bahwa secara rata-rata Pemda baru dapat mencukupi $19.82 \%$ dari kebutuhan auditor internalnya. Nilai minimum dari IA_PERC adalah 0.01 atau 1\% yang muncul pada 158 Pemda dan nilai maksimum sebesar 1.45 atau 145\% yaitu pada Kab. Sambas, yang berarti bahwa 158 Pemda baru dapat mencukupi 1\% dari kebutuhan auditornya dan Kab. Sambas telah memiliki auditor internal 45\% lebih banyak dari kebutuhan auditornya. Variabel DIKLAT menunjukkan rata-rata sebanyak 4.6182 yang berarti bahwa rata-rata setiap Pemda mengirimkan sekitar 5 orang untuk melaksanakan diklat pada Pusdiklatwas BPKP. Nilai minimal variabel DIKLAT adalah 0 orang pada 89 Pemda dan maksimal adalah 52 orang yaitu pada Kab. Tangerang. Variabel SIMDA_KEU, SIMDA_BMD, SIMDA_GAJI, dan SIMDA_PEND adalah variabel dummy, yaitu nilai 0 pada Pemda yang tidak mengimplementasikan SIMDA terkait dan nilai 1 pada Pemda yang mengimplementasikan SIMDA terkait. Rata-rata variabel SIMDA_KEU menunjukkan 0.6333, yang berarti bahwa 63,33\% Pemda telah 
mengimplementasikan SIMDA Keuangan. Rata-rata variabel SIMDA_BMD menunjukkan 0.5970, yang berarti bahwa 59.70\% Pemda telah mengimplementasikan SIMDA BMD. Rata-rata variabel SIMDA_Gaji menunjukkan 0.1848, yang berarti bahwa 18.48\% Pemda telah mengimplementasikan SIMDA Gaji. Rata-rata variabel SIMDA_PEND menunjukkan 0.0697, yang berarti bahwa 6,97\% Pemda telah mengimplementasikan SIMDA Pendapatan.

Tabel 2. Statistik Deskriptif $(n=330)$

\begin{tabular}{lrrrr}
\hline \multicolumn{1}{c}{ Variabel } & \multicolumn{1}{c}{ Min. } & Max. & \multicolumn{1}{c}{ Mean } & \multicolumn{1}{c}{ Std. Dev. } \\
\hline ARL & -12.00 & 17.00 & -2.3242 & 2.87231 \\
IA_PERC & .01 & 1.45 & .1982 & .28617 \\
TRAIN & .00 & 52.00 & 4.6182 & 6.80289 \\
SIMDA_KEU & .00 & 1.00 & .6333 & .48263 \\
SIMDA_BMD & .00 & 1.00 & .5970 & .49125 \\
SIMDA_GAJI & .00 & 1.00 & .1848 & .38876 \\
SIMDA_PEND & .00 & 1.00 & .0697 & .25502 \\
BAST_LAG & -56.00 & 147.00 & 2.5758 & 24.45905 \\
EXP & 342.50 & 4914.83 & 1063.4093 & 605.75826 \\
TYPE & 1.00 & 3.00 & 2.7667 & .46466 \\
SKPD & 24.00 & 108.00 & 50.8939 & 16.61373
\end{tabular}

Keterangan $: A R L=$ Audit Report Lag, IA_PERC $=$ Persentasi kecukupan APIP, TRAIN = Jumlah orang yang mengikuti diklat pada Pusdiklatwas, SIMDA_KEU = Implementasi SIMDA Keuangan, SIMDA_BMD = Implementasi SIMDA Barang Milik Daerah, SIMDA_GAJI = Implementasi SIMDA Gaji, SIMDA_PEND = Implementasi SIMDA Pendapatan, BAST_LAG = Lag penyampaian LKPD dari Pemda kepada BPK, EXP = Total Belanja Daerah, TYPE = Tipe Pemda, SKPD = Jumlah SKPD

Variabel kontrol yang digunakan dalam penelitian ini adalah BAST, EXP, TYPE, dan SKPD. Variabel EXP yang digunakan dalam penelitian ini adalah belanja dalam milyar rupiah, sehingga rata-rata belanja Pemda pada penelitian ini adalah 1.063 trilyun rupiah. TYPE menunjukkan jenis Pemda yaitu 1 untuk Provinsi, 2 untuk Kota, dan 3 untuk Kabupaten. SKPD adalah jumlah SKPD yang dimiliki oleh Pemda. Rata-rata Pemda memiliki 50.8939 SKPD. 
Tabel 3. Hasil Pengujian Hipotesis

\begin{tabular}{lcccc}
\hline \multicolumn{1}{c}{ Variabel } & N & Beta & t & Sig. \\
\hline (Constant) & & & 1.602 & 0.110 \\
JFA_PER & 330 & -0.095 & -1.916 & $0.056^{* * *}$ \\
TRAIN & 330 & -0.095 & -1.920 & $0.056^{* * *}$ \\
SIMDA_KEU & 330 & 0.081 & 1.455 & 0.147 \\
SIMDA_BMD & 330 & -0.179 & -3.249 & $0.001^{*}$ \\
SIMDA_GAJI & 330 & -0.095 & -1.794 & $0.074^{* * *}$ \\
SIMDA_PENDAP & 330 & -0.023 & -0.461 & 0.645 \\
BAST_LAG & 330 & 0.259 & 5.298 & $0.000^{*}$ \\
EXP & 330 & -0.366 & -7.112 & $0.000^{*}$ \\
TYPE & 330 & 0.210 & 4.252 & $0.000^{*}$ \\
SKPD & 330 & -0.009 & -0.171 & 0.864 \\
\hline R SQUARE & & 0.269 & & \\
Adj. R SQUARE & & 0.247 & & \\
F Value & & 11.768 & & 0,000 \\
Sig. & & & & \\
\hline
\end{tabular}

Keterangan: $A R L=$ Audit Report Lag, IA_PERC $=$ Persentasi kecukupan APIP, TRAIN = Jumlah orang yang mengikuti diklat pada Pusdiklatwas, SIMDA_KEU = Implementasi SIMDA Keuangan, SIMDA_BMD = Implementasi SIMDA Barang Milik Daerah, SIMDA_GAJI = Implementasi SIMDA Gaji, SIMDA_PEND = Implementasi SIMDA Pendapatan, BAST_LAG = Lag penyampaian LKPD dari Pemda kepada BPK, EXP = Total Belanja Daerah, TYPE = Tipe Pemda SKPD = Jumlah SKPD, * = signifikansi $1 \%,{ }^{* *}=$ signifikansi $5 \%,{ }^{* * *}=$ signifikansi $10 \%$

Sebagai syarat pengujian dengan model regresi, penelitian telah melakukan pengujian asumsi klasik yang terdiri dari uji normalitas data, uji heteroskedastisitas, dan uji multikolinearitas dengan hasil bahwa model yang digunakan terbebas dari semua asumsi klasik. Setelah itu dilakukan pengujian hipotesis dengan menggunakan persamaan regresi seperti tersebut di atas dan hasil yang diperoleh dapat disajikan dalam Tabel 3. 
Uji signifikansi-F menunjukkan apakah semua variabel independen (bebas) yang dimasukkan dalam model berpengaruh secara bersama-sama terhadap variabel dependen (terikat) Hasil uji signifikansi F dapat dilihat pada Tabel 3. Model regresi pada penelitian ini menunjukkan nilai sig. 0.000 yang berarti memenuhi kriteria sehingga model regresi layak.

Pengujian koifisien determinasi $\left(\mathrm{R}^{2}\right)$ digunakan untuk mengukur kemampuan model dalam menjelaskan variansi variabel dependen. Hasil uji koefisien determinasi dapat dilihat pada Tabel 3. Berdasarkan Tabel 3 diketahui bahwa nilai Adjusted $R$ Square adalah 0.269 atau sebesar 26.9\%. Hal tersebut mengindikasikan bahwa variabel independen SKPD, SIMDA_GAJI, BAST, TRAIN, TYPE, IA_PERC, SIMDA_PEND, SIMDA_BMD, EXP, SIMDA_KEU mampu menjelaskan variabel dependen ARL sebesar 26.9\% dan sisanya sebesar 74.1\% dijelaskan oleh variabel lain di luar model penelitian ini.

Uji $t$ digunakan untuk menguji apakah variabel independen secara signifikan dapat menjelaskan variabel dependennya. Jika nilai signifikansi $t<0.10$, maka hipotesis tidak dapat ditolak, sehingga variabel independen berpengaruh signifikan terhadap variabel dependen. Sebaliknya, jika nilai signifikansi t $>0.10$, maka variabel independen dianggap tidak memiliki pengaruh yang signifikan terhadap variabel dependen. Hasil uji signifikansi t dapat dilihat pada Tabel 3, nilai Beta menunjukkan arah dari pengaruh variabel.

Penelitian ini menggunakan audit report lag (ARL) sehagai variabel dependen, pengalokasian sumber daya ekonomi terkait IAF yang diproksikan dengan persentase kecukupan auditor dan jumlah peserta diklat pada Pusdiklatwas dan asistensi BPKP yang diproksikan dengan implementasi SIMDA Keuangan, implementasi SIMDA BMD, implementasi SIMDA Gaji, dan implementasi SIMDA Pendapatan sebagai variabel independen, serta Penyerahan LKPD dari Pemda kepada BPK dan ukuran daerah (SIZE) yang diproksikan dengan total belanja daerah, tipe penerintah daerah, dan jumlah SKPD sebagai variabel kontrol. Hasil pengujian yang telah dilakukan dalam penelitian ini membuktikan bahwa hipotesis pertama, kedua, keempat dan kelima dapat diterima, sedangkan hipotesis ketiga dan keenam ditolak. 
Tabel 3 menunjukkan bahwa hipotesis pertama, yaitu persentase kecukupan auditor internal Pemda (inspektorat daerah) berpengaruh negatif terhadap ARL, diterima. Artinya, bertambahnya kecukupan auditor internal Pemda akan mempercepat proses audit yang dilakukan oleh BPK. Hal ini dapat dijelaskan bahwa sesuai dengan pendapat Prawitt, dkk. (2009), IAF yang dibiayai dengan baik seharusnya memiliki kemampuan monitoring yang lebih baik untuk mendeteksi dan mencegah kesalahan pengungkapan yang materiil. Dengan sumber daya yang lebih baik, dalam hal ini adalah kecukupan tenaga auditor internal, audit internal akan mengurangi defisiensi pengendalian, sehingga auditor eksternal akan mengurangi jumlah bukti yang dikumpulkan, sehingga dapat mempercepat proses audit. Hasil penelitian ini sejalan dengan hasil penelitian Wan-Hussin dan Bamahros (2013) yang menemukan hubungan yang negatif antara biaya yang dikeluarkan untuk IAF terhadap audit delay.

Menurut International Professional Practices Framework (IPPF), The Institute of Internal Auditors Research Foundation (2011), internal audit adalah aktivitas assurance dan consulting yang independen dan objektif yang didesain untuk menambah nilai dan meningkatkan operasional organisasi. Menurut Standar Profesi Audit Internal (2004), fungsi audit internal terdiri atas fungsi perencanaan, komunikasi dan persetujuan, pengelolaan sumber daya, kebijakan dan prosedur, koordinasi, dan laporan kepada pemimpin dan dewan pengawas. Biaya yang dikeluarkan untuk fungsi internal audit tersebut umumnya terdiri atas jumlah orang, pelatihan, outsourcing kepada penyedia jasa, dan perjalanan dinas. Prawitt, dkk. (2009) berpendapat bahwa fungsi internal audit yang dibiayai dengan baik seharusnya memiliki kemampuan monitoring yang lebih baik untuk mendeteksi dan mencegah kesalahan pengungkapan yang materiil. Dengan sumber daya yang lebih baik, dapat diupayakan agar fungsi internal audit memiliki jumlah personel yang cukup dan kompeten.

Menurut Lin, dkk. (2011), pekerjaan fungsi internal audit adalah pengendalian pelaporan keuangan dan kualitas fungsi internal audit akan meningkatkan efektivitas pengendalian laporan keuangan. Wan-Hussin dan Bamahros (2013) berpendapat bahwa meningkatnya investasi pada fungsi audit 
internal akan mengurangi defisiensi pengendalian, sehingga auditor eksternal akan mengurangi jumlah bukti yang dikumpulkan, sehingga dapat mempercepat proses audit. Hal ini didukung oleh penelitian Ettredge, dkk. (2006) yang menemukan bahwa perusahaan yang memiliki kelemahan pengendalian laporan keuangan akan cenderung memiliki audit delay yang lebih panjang daripada yang tidak memiliki kelemahan pengendalian laporan keuangan. Wan-Hussin dan Bamahros (2013) menemukan hubungan yang negatif antara biaya yang dikeluarkan untuk IAF terhadap audit delay.

Berdasarkan logika tersebut, jika diturunkan dari definisi biaya yang dikeluarkan untuk IAF, jumlah auditor internal yang berada di dalam suatu entitas akan dapat mengurangi defisiensi pengendalian. Dengan berkurangnya defisiensi pengendalian, auditor eksternal akan mengurangi jumlah bukti yang dikumpulkan, sehingga dapat mempercepat proses audit, dengan kata lain, mengurangi ARL.

Jika logika di atas ditarik ke sektor publik, dalam hal ini terkait dengan Pemerintah Provinsi/Kabupaten/Kota, kecukupan jumlah personil auditor internal pada Inspektorat Provinsi/Kabupaten/Kota akan dapat mempercepat proses audit, dengan kata lain, mengurangi ARL. Terkait dengan kecukupan jumlah personel, BPKP selaku pembina APIP telah menerbitkan Keputusan Kepala BPKP No. KEP:971/K/SU/2005 tentang Pedoman Penyusunan Formasi Jabatan Fungsional Auditor di Lingkungan Aparat Pengawasan Internal Pemerintah untuk menghitung jumlah kebutuhan personel APIP untuk masing-masing daerah. Karena kebutuhan auditor internal Pemda dapat dihitung, maka kecukupan jumlah auditor Pemda dapat didefinisikan ketersediaan auditor pemerintah daerah atas jumlah kebutuhan auditor bagi pemerintah daerah

Hipotesis kedua bahwa jumlah peserta diklat Pemda (inspektorat daerah) pada Pusdiklatwas BPKP berpengaruh negatif terhadap ARL diterima berdasarkan hasil pengujian hipotesis. Hal ini sejalan dengan hasil penelitian Wan-Hussin dan Bamahros (2013) bahwa terdapat hubungan yang negatif antara biaya yang dikeluarkan untuk IAF terhadap audit delay. Hal ini dapat dijelaskan bahwa diklat yang dilakukan oleh auditor internal di dalam suatu entitas juga akan meningkatkan kompetensi auditor sehingga dapat mengurangi defisiensi pengendalian. Dengan 
berkurangnya defisiensi pengendalian, auditor eksternal akan mengurangi jumlah bukti yang dikumpulkan, sehingga dapat mempercepat proses audit, atau dengan kata lain akan mengurangi ARL.

Pada sektor publik, berbeda dengan sektor swasta, Pemda tidak selalu mengeluarkan biaya untuk menyelenggarakan diklat bagi pegawai internalnya, sehingga akan sulit untuk mengukur biaya diklat yang dikeluarkan oleh Pemda. Namun, khusus terkait dengan diklat terkait IAF, BPKP memiliki lembaga pendidikan dan pelatihan yang disebut Pusat Pendidikan dan Pelatihan Pengawasan (Pusdiklatwas). Pusdiklatwas BPKP adalah lembaga yang bertugas untuk membangun kompetensi seluruh APIP di tingkat pusat dan daerah dengan menyelenggarakan pendidikan dan pelatihan pengawasan untuk pelaksanaan pembangunan dan pelaksanaan tugas-tugas umum pemerintahan serta pembinaan aparatur pemerintah yang lebih baik. Jumlah auditor internal pada Inspektorat Provinsi/Kabupaten/Kota yang mengikuti diklat pada Pusdiklatwas BPKP dapat dianggap sebagai bagian dari investasi/pengalokasian sumber daya ekonomi oleh Pemda terhadap IAF.

Hipotesis ketiga bahwa penerapan SIMDA Keuangan berpengaruh negatif terhadap ARL ditolak. Hal tersebut berarti bahwa penerapan SIMDA Keuangan tidak dapat memberikan dampak percepatan terhadap proses audit oleh BPK. Penulis menduga bahwa penyebab tidak berpengaruhnya penerapan SIMDA Keuangan adalah karena SIMDA Keuangan berfokus kepada proses akuntansi keuangan Pemda, yang meliputi penyusunan anggaran, penatausahaan, akuntansi, dan pelaporan. Dengan atau tanpa SIMDA Keuangan, Pemda tetap harus membuat LKPD. Artinya, apabila tidak menggunakan SIMDA Keuangan, Pemda dapat menggunakan aplikasi lain atau membuatnya secara manual dengan hasil output yang sama dengan ketika menggunakan SIMDA Keuangan. Karena hasil output adalah LKPD yang sama dan dengan format yang telah ditentukan, hal tersebut tidak dijadikan pertimbangan oleh BPK dalam penentuan sampel dan pengujian, sehingga tidak mempercepat proses audit BPK.

Pada sektor swasta, IAF dapat dilaksanakan oleh pihak internal (in-house), pihak eksternal (outsource), atau gabungan antara keduanya (co-source). Menurut 
Adams (2013), salah satu isu yang relevan terkait dengan profesi internal audit adalah outsourcing dari jasa internal audit oleh akuntan di luar entitas. Kekurangan dari jasa internal auditor dari luar adalah hilangnya loyalitas, pemahaman atas bisnis, dan hilangnya pengalaman serta pelatihan dari pihak internal.

Ahlawat dan Lowe (2004) menemukan bahwa IAF secara out-source lebih objektif daripada IAF yang dikelola sendiri oleh perusahaan. Glovers, dkk. (2008) menemukan bahwa ketika risiko inheren tinggi, auditor eksternal akan lebih memilih untuk percaya kepada hasil kerja auditor internal out-source daripada yang menggunakan auditor internal in-house. Abbott, dkk. (2012) menunjukkan bahwa asistensi langsung dari IAF kepada eksternal auditor menimbulkan efisiensi yang lebih baik dan mengurangi ARL. Berdasarkan hasil penelitian sebelumnya tersebut, sejalan dengan penelitian Wan-Hussin dan Bamahros (2013) dan Abbott, dkk. (2012), penulis menduga bahwa akan ditemukan hubungan antara sourcing arrangement dari IAF terhadap ARL.

Pada sektor publik, untuk melaksanakan IAF tersebut, sesuai dengan amanat Pasal 58 Undang-Undang No. 1 tahun 2004 tentang Perbendaharaan Negara, diselenggarakan sistem pengendalian internal di lingkungan pemerintahan secara menyeluruh dengan sistem yang disebut dengan Sistem Pengendalian Intern Pemerintah (SPIP). SPIP dilaksanakan oleh Aparat Pengawasan Intern Pemerintah (APIP), yang terdiri atas: BPKP yang melakukan pengawasan intern terhadap akuntabilitas keuangan negara atas kegiatan tertentu, meliputi kegiatan yang bersifat lintas sektoral, kegiatan kebendaharaan umum negara, dan kegiatan lain berdasarkan penugasan dari Presiden. Selain itu, Inspektorat Jenderal atau nama lain yang secara fungsional melaksanakan pengawasan intern terhadap seluruh kegiatan dalam rangka penyelenggaraan tugas dan fungsi Kementerian/Lembaga yang didanai dengan Anggaran Pendapatan dan Belanja Negara (APBN), dan Inspektorat Provinsi/Kabupaten/Kota yang melakukan pengawasan terhadap seluruh kegiatan dalam rangka penyelenggaraan tugas dan fungsi satuan kerja perangkat daerah provinsi yang didanai dengan Anggaran Pendapatan dan Belanja Daerah (APBD) Provinsi/Kabupaten/Kota. 
Berdasarkan deskripsi tersebut, berbeda dengan sektor swasta, seluruh Pemda provinsi/Kabupaten/Kota memiliki auditor in-house yaitu Inspektorat Provinsi/Kabupaten/Kota yang bertugas menyelenggarakan SPIP pada lingkup pemerintahannya. Dengan demikian, tidak ada fungsi auditor internal yang hanya dilaksanakan oleh pihak eksternal saja (pure out-sourcing).

BPKP, selain melaksanakan tugas di atas, juga ditunjuk sebagai pembina penyelenggaraan SPIP yang memiliki tugas antara lain penyusunan pedoman teknis penyelenggaraan SPIP, sosialisasi SPIP, pendidikan dan pelatihan SPIP, dan peningkatan kompetensi auditor APIP. Terkait dengan pelaksanaan dan pembinaan SPIP, dengan munculnya Instruksi Presiden Republik Indonesia No. 4 tahun 2011 tentang Percepatan Peningkatan Kualitas Akuntabilitas Keuangan Negara, BPKP diinstruksikan untuk melaksanakan asistensi kepada kementerian/lembaga/Pemda, evaluasi terhadap penyerapan anggaran, audit tujuan tertentu terhadap programprogram strategis nasional, dan rencana aksi yang jelas, tepat, dan terjadwal dalam mendorong penyelenggaraan SPIP.

Terkait dengan pelaksanaan amanat tersebut, BPKP memandang perlu untuk memfasilitasi Pemda dalam mempersiapkan aparatnya menghadapi perubahan, mendorong pelaksanaan tata kelola keuangan daerah sesuai dengan peraturan yang berlaku, efisien, efektif, transparan, akuntabel, dan auditabel. BPKP membentuk Satuan Tugas Pengembangan Sistem Informasi Manajemen Daerah (SIMDA) untuk mendukung tujuan tersebut.

Terdapat 4 jenis aplikasi SIMDA yang saat ini dapat digunakan oleh Pemda dalam penyusunan Laporan Keuangan, yaitu SIMDA Keuangan, SIMDA Barang Milik Daerah (BMD), SIMDA Gaji, dan SIMDA Pendapatan. SIMDA Keuangan berfokus kepada proses akuntansi keuangan Pemda. SIMDA BMD berfokus pada pengelolaan barang milik daerah. SIMDA Gaji berfokus pada siklus gaji dan upah pada Pemda. SIMDA Pendapatan berfokus kepada optimalisasi pajak/retribusi serta laporan pendapatan dan piutang. Penggunaan SIMDA oleh Pemda ini tidak bersifat wajib, sehingga Pemda dapat memilih untuk menggunakan atau tidak menggunakan sebagian atau seluruh aplikasi SIMDA. Penggunaan SIMDA oleh Pemda akan terus dipantau oleh Satuan Tugas Pengembangan SIMDA, dan diasistensi oleh BPKP 
melalui Kantor Perwakilan BPKP pada Provinsi yang bersangkutan.

Berdasarkan penjelasan tersebut, auditor Internal in-house pada lingkungan Pemda Provinsi/Kabupaten/Kota dapat dipersamakan dengan Inspektorat Provinsi/Kabupaten/Kota, karena Inspektorat, berdasarkan ketentuan, merupakan satuan kerja perangkat daerah di dalam lingkup pemerintahan Provinsi/Kabupaten/Kota tersebut. BPKP, yang merupakan auditor internal negara, berada di luar lingkungan Provinsi/Kabupaten/Kota. Asistensi BPKP dalam bentuk pengembangan SIMDA pada Pemda merupakan usaha membantu Pemda untuk melaksanakan tata kelola keuangan daerah sesuai dengan peraturan yang berlaku, efisien, efektif, transparan, akuntabel, dan auditabel. Oleh karena itu, bimbingan teknis/asistensi BPKP dapat dipandang sebagai bantuan tenaga out-source dalam melaksanakan IAF.

Penelitian Wan-Hussin dan Bamahros (2013) tidak menemukan hubungan antara sourcing arrangement dari IAF terhadap ARL. Namun, penulis menduga bahwa asistensi langsung dari BPKP terhadap penyusunan laporan keuangan dengan menggunakan SIMDA terhadap ARL dapat mengurangi defisiensi pengendalian. Dengan berkurangnya defisiensi pengendalian, auditor eksternal akan mengurangi jumlah bukti yang dikumpulkan, sehingga diharapkan dapat mempercepat proses audit, dengan kata lain, mengurangi ARL.

Hipotesis keempat bahwa penerapan SIMDA BMD berpengaruh negatif terhadap ARL terbukti berdasarkan hasil pengujian hipotesis. Hal ini berarti bahwa implementasi SIMDA BMD oleh Pemda dapat mempercepat proses audit oleh BPK. Terdapat perbedaan pengaruh antara implementasi SIMDA Keuangan dengan SIMDA BMD. Karena SIMDA BMD berfokus kepada pengelolaan barang milik daerah, meliputi perencanaan, pengadaan, penatausahaan, penghapusan, dan akuntansi barang milik daerah,, yang merupakan aset daerah, SIMDA BMD dapat memperkuat pengendalian internal Pemda terhadap aset daerah. Berdasarkan data IHPS I dan II tahun 2013, penatausahaan aset daerah merupakan salah satu bagian yang paling bermasalah dan dijadikan fokus oleh BPK dalam pemeriksaannya. Berpengaruhnya SIMDA BMD terhadap ARL mengindikasikan bahwa SIMDA BMD memberikan meningkatkan pengendalian internal terhadap pengelolaan BMD, yang kemudian 
dapat mengurangi sampel audit dan mempermudah proses audit BPK sehingga mempercepat proses audit.

Hipotesis kelima bahwa penerapan SIMDA Gaji berpengaruh negatif terhadap ARL terbukti. Hal ini berarti bahwa implementasi SIMDA Gaji oleh Pemda dapat mempercepat proses audit oleh BPK. SIMDA Gaji berfokus pada siklus penggajian yang merupakan salah satu siklus yang menjadi perhatian auditor dalam melakukan pemeriksaan. Hasil pengujian membuktikan bahwa penggunaan SIMDA Gaji akan memperbaiki pengendalian terhadap siklus penggajian, sehingga auditor dapat mengurangi sampel audit dan mempermudah proses audit BPK terkait siklus penggajian sehingga mempercepat proses audit.

Berdasarkan hasil pengujian, hipotesis keenam bahwa penerapan SIMDA Pendapatan berpengaruh negatif terhadap ARL ditolak. Penulis menduga hal ini terjadi karena hanya berdasarkan hasil statistik deskriptif, pengguna SIMDA Pendapatan hanya sebesar 6.97\%, yang berarti bahwa SIMDA Pendapatan belum diimplementasikan secara luas kepada Pemda, dan perlu dikembangkan lebih lanjut oleh BPKP.

Hasil pengujian terhadap variabel kontrol menemukan bahwa penyerahan LKPD dari Pemda kepada BPK, belanja daerah, dan tipe pemerintahan daerah berpengaruh terhadap ARL. penyerahan LKPD dari Pemda kepada BPK berpengaruh terhadap ARL sejalan dengan aturan terkait batas waktu pemeriksaan BPK dikaitkan dengan kenyataan bahwa jumlah auditor BPK yang masih kurang Penulis menduga bahwa BPK akan memprioritaskan kepada LKPD yang masuk terlebih dahulu, sehingga kekurangan personil mengakibatkan LKPD yang terlambat tidak mendapatkan personil untuk mengaudit LKPD tersebut. Pengaruh negatif belanja daerah dapat dijelaskan bahwa semakin besar belanja yang di miliki oleh pemerintahan maka pemerintah mampu memanfaatkan sumber daya tersebut untuk memiliki teknologi, fasilitas, serta sumber daya yang lebih baik sehingga mampu menyusun laporan keuangan serta memiliki akses daerah yang baik dan akhirnya dapat mengurangi ARL. Pengaruh positif tipe daerah dapat dijelaskan bahwa sesuai Pizzini, dkk. (2015), pemerintah yang lebih besar akan cenderung mengalami peningkatan jumlah transaksi keuangan, sehingga akan lebih memakan 
waktu untuk melakukan audit dan menghasilkan ARL yang lebih banyak.

Tidak ditemukan hubungan antara ARL dengan jumlah SKPD. Pemda yang memiliki lebih banyak SKPD akan membutuhkan pertanggungjawaban keuangan yang lebih banyak. Namun, tidak ditemukan pengaruh yang signifikan antara jumlah SKPD dengan ARL. Bertambahnya SKPD tidak langsung berarti bahwa proses audit akan berlangsung lebih lama.

\section{Simpulan}

Penelitian ini bertujuan untuk mengetahui pengaruh internal audit dan asistensi BPKP terhadap audit reporting lag pada Pemda di Indonesia. Hasil penelitian ini menyimpulkan bahwa internal audit, yang diproksikan oleh kecukupan jumlah auditor internal dan jumlah orang yang melaksanakan diklat pada Pusdiklatwas berpengaruh secara signifikan terhadap audit reporting lag. Sebagian pelaksanaan asistensi BPKP, yaitu implementasi SIMDA BMD dan SIMDA Gaji pada Pemda berpengaruh signifikan terhadap audit reporting lag. Implementasi SIMDA Keuangan dan SIMDA Pendapatan tidak berpengaruh secara signifikan terhadap audit reporting lag.

Penelitian ini memiliki keterbatasan yang dapat mempengaruhi hasil penelitian. Penelitian ini tidak menentukan sampel dengan menggunakan random sampling, sehingga hasil tidak sepenuhnya digeneralisasi pada seluruh populasi. Hal tersebut dikarenakan tidak semua anggota populasi tidak memiliki hak yang sama untuk menjadi sampel Penelitian ini menggunakan pengukuran non-keuangan untuk menilai alokasi sumber daya ekonomi terhadap fungsi auditor internal, yaitu kecukupan auditor dan pelaksanaan diklat, sehingga tidak dapat sepenuhnya menggambarkan alokasi sumber daya ekonomi terhadap fungsi auditor internal. Hal ini harus dilakukan karena data keuangan terkait pengalokasian anggaran terkait fungsi auditor internal, seperti anggaran inspektorat pada Pemda di seluruh indonesia, tidak bisa didapatkan. Hal tersebut dikarenakan tidak ditemukan lembaga yang secara khusus mengumpulkan data tersebut sehingga pengumpulan data secara nasional. Asistensi BPKP yang dibahas dalam penelitian ini terbatas kepada asistensi yang berkaitan langsung dengan penyusunan laporan keuangan, yaitu implementasi SIMDA. Pada kenyataannya, banyak asistensi lain yang juga dilakukan 
oleh BPKP yang tidak langsung berkaitan dengan penyusunan laporan keuangan.

Hasil penelitian ini menunjukkan kecukupan jumlah auditor internal dan jumlah orang yang melaksanakan diklat pada Pusdiklatwas berpengaruh secara signifikan terhadap audit reporting lag. Berdasarkan hasil tersebut, diharapkan Pemda dapat menambah jumlah auditor internal sehingga mencukupi formasi auditor internal yang dibutuhkan. Pemda juga diharapkan untuk memberikan lebih banyak pendidikan dan pelatihan kepada auditor internalnya untuk meningkatkan kompetensi sehingga diharapkan Pemda melaksanakan IAF dengan lebih baik. Penelitian ini juga mengindikasikan bahwa alokasi sumber daya ekonomi terhadap IAF Pemda berpengaruh secara signifikan terhadap audit report lag, sehingga pemerintah diharapkan untuk meningkatkan pengalokasian sumber daya ekonomi terkait dengan IAF.

Implementasi SIMDA BMD dan SIMDA Gaji pada Pemda berpengaruh signifikan dalam mengurangi audit report lag, yang mengindikasikan bahwa penerapan SIMDA BMD dan SIMDA Gaji dapat meningkatkan pengendalian internal terhadap pengelolaan Barang Milik Daerah dan siklus penggajian. Dari hasil penelitian tersebut, Pemda yang belum mengimplementasikan SIMDA BMD dan SIMDA Gaji dapat mulai mengimplementasikan SIMDA BMD dan SIMDA Gaji pada Pemdanya untuk meningkatkan pengendalian internal terhadap pengelolaan Barang Milik Daerah dan siklus penggajian.

\section{PUSTAKA ACUAN}

Abbott, Lawrence J., Susan Parker, and Gary F. Peters. 2012. Internal Audit Assistance and External Audit Timeliness. AUDITING: A Journal of Practice \& Theory. Vol. 31 (4): 3-20.

Abernathy, J.L., B. Beyer, A. Masli, \& C.M. Stefaniak. (2015). How the Source of Audit Committee Accounting Expertise Influences Financial Reporting Timeliness. Current Issues in Auditing. Vol. 9 (1): P1-P9.

Ahlawat, S.S., \& D.J. Lowe. (2004). An Examination of Internal Auditor Objectivity: In-House versus Outsourcing. AUDITING: A Journal of Practice \& Theory. Vol. 23 (2):147-158..

Adams, M.B. (2013). Agency Theory and the Internal Audit. Managerial Auditing 
Journal, Vol. 9 (Issue: 8): 8 - 12 .

Cohen, S., \& S. Leventis. (2013). Effects of Municipal, Auditing and Political Factors on Audit Delay. Accounting Forum. Vol. 37 (1): 40-53.

Desai, N.K., G.J. Gerard, and A. Tripathy. (2011). Internal Audit Sourcing Arrangements and Reliance by External Auditors. AUDITING: A Journal of Practice \& Theory. Vol 30 (1): 149-171.

Ettredge, M.L., C. Li, \& L. Sun. (2006). The Impact of SOX Section 404 Internal Control Quality Assessment on Audit Delay in the SOX Era. AUDITING: A Journal of Practice \& Theory. Vol. 25 (2): 1-23.

Glovers, S.M., D.F. Prawitt, \& D.A.. Wood. (2008). Internal Audit Sourcing Arrangement and the External Auditor's Reliance Decision. Contemporary Accounting Research. Vol 25 (1): 193-213.

Lin, S., M. Pizzini., M. Vargus, \& I.R. Bardhan. (2011). The Role of The Internal Audit Function in The Disclosure of Material Weaknesses. The Accounting Review. Vol. 86 (1): 287-323.

Naimi, M., M. Nor., S. Rohami, \& W.N.Wan-Hussin. (2010). Corporate Governance and Audit Report Lag in Malaysia. AAMJAF. Vol. 6 (2):57-84.

Pizzini, M., S. Lin, \& D.E. Ziegenfuss. (2015). The Impact of Internal Audit Function Quality and Contribution on Audit Delay. Auditing: A Journal of Practice \& Theory. Vol 34 (1): 25-58.

Prawitt, D.F., J.L. Smith, \& D.A. Wood. (2009). Internal audit quality and earnings management. The Accounting Review. Vol. 84 (4): 1255-1280.

Wan-Hussin, W.N, \& H.M. Bamahros. (2013). Do Investment In and The Sourcing Arrangement of The Internal Audit Function Affect Audit Delay? Journal of Contemporary Accounting \& Economics. Vol. 9 (1): 19-32. 